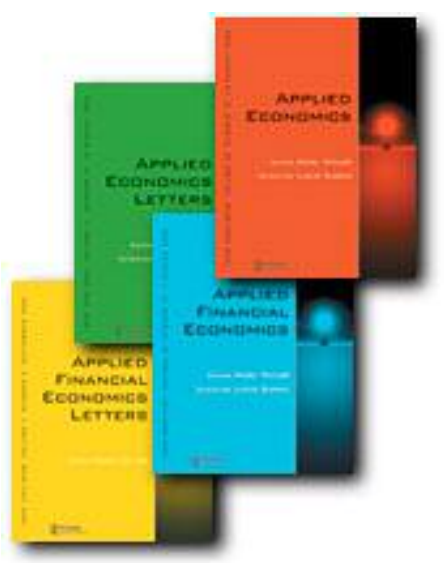

Relative Prices and Inflation: New Evidence from Different Inflationary Contexts

\begin{tabular}{|r|l|}
\hline Journal: & Applied Economics \\
\hline Manuscript ID: & APE-04-0153.R1 \\
\hline Journal Selection: & Applied Economics \\
\hline Date Submitted by the \\
Author: & 28-Jan-2005 \\
\hline JEL Code: & $\begin{array}{l}\text { E31 - Price Level|Inflation|Deflation < E3 - Prices, Business } \\
\text { Fluctuations, and Cycles < E - Macroeconomics and Monetary } \\
\text { Economics }\end{array}$ \\
\hline Keywords: & $\begin{array}{l}\text { inflation, relative price variabilty, inflation regimes, inflation } \\
\text { volatility, expected and unexpected inflation }\end{array}$ \\
\hline
\end{tabular}

powered by ScholarOne

Manuscript Central ${ }^{\text {H }}$ 


\title{
Relative Prices and Inflation: New Evidence from Different Inflationary Contexts
}

\begin{abstract}
This paper analyzes the relationship between inflation and relative price variability, in the direction of the latter, in two countries with very different inflationary experiences: Argentina and Spain. To address this objective, using disaggregated price indexes (the Wholesale Price Index for Argentina and the Consumer Price Index for Spain), we delimitate different inflationary regimes and compute a set of regressions for each country. Our results suggest evidence in favour of the non-neutrality of inflation (mostly in hyperinflation periods) and do not support either the menu costs or the signal extraction approaches. We also detect significant structural changes in the relationship depending on the inflationary regime.
\end{abstract}




\section{Relative Prices and Inflation: New Evidence from Different Inflationary Contexts}

\section{Introduction}

Empirical evidence suggests that inflation and higher moments of the relative price changes distribution are strongly positively correlated. This fact supports the hypothesis of non-neutrality of inflation; moreover, it denotes that inflation is costly since it affects the distribution of relative prices in the economy, distorting the information content of nominal price.

In particular, there is a vast empirical literature studying the relationship between inflation and relative price variability (RPV), the second moment of the relative price changes distribution, defined as the standard deviation of the individual rate of price change around the average inflation rate -that is, intermarket RPV. ${ }^{1}$ The empirical work dates back to Mills (1927), who provided a description of the United States (US) price system. The contributions of Vining and Elwertowski (1976) and, especially, Parks (1978) are the landmarks. These authors found that for different countries inflation and intermarket RPV are positively correlated over time. ${ }^{2}$ This positive correlation has been confirmed by the large body of empirical work done since then (Parks (1978) for the Netherlands and US, Fischer $(1981,1982)$ for US and Germany, Blejer and Leiderman (1982) and Palerm (1991) for Mexico, and Tommasi (1993) and Dabús (2000) for Argentina, among others). Other studies compare the RPVinflation relationship in several geographical areas. Parsley (1996) and Debelle and Lamont (1997), for example, look at several cities of the US, Fielding and Mizen (2000) examine ten countries of the European Union, and Caraballo and Usabiaga (2004a) look at the 17 regions of Spain. In all of these studies a positive correlation between RPV and inflation is reported. 
Empirical evidence thus supports a positive relationship between RPV and inflation, but there is no consensus about the causal mechanism that generates this relationship. A variety of theories can explain this empirical fact; the prevalent ones are menu costs and signal extraction models. The first emphasizes the role of expected inflation while the second is focused on the effects of unexpected inflation.

On the one hand, the menu costs model assumes that price adjustments are costly, which implies that firms respond using a $(S, S)$ pricing rule. According to this rule, the firm holds its nominal price constant and lets inflation erode the real price of its products until it reaches the lower bound s. Then nominal price is adjusted such that the new real price is equal to the upper bound $S$. If inflation increases, the firms will widen the distance between the optimal $s$ and $S$. Moreover, if menu costs are different among firms, or firms experience specific shocks, staggered price setting will arise, exacerbating the effect of higher inflation on RPV. Therefore, menu costs models suggest a positive correlation between RPV and expected inflation.

The signal extraction model, on the other hand, states that as inflation is not always anticipated correctly, it creates "misperceptions" of absolute and relative prices generating an increase in RPV. Hence, increased unexpected inflation will raise RPV.

Empirical evidence in this area is mixed, in the sense that there are studies supporting the menu costs model, the signal extraction model, both or neither of them. The existing literature is huge, in particular for the US. The results of some of the most relevant papers are summarized in the following table:

\section{Table 1}

Finally, some authors attend to the inflation volatility as a determinant of RPV, especially in inflationary economies. In this sense, Logue and Willet (1976) 
and Blejer (1979) for several Latin American countries, Moura and Kadota (1982) for Brazil and Dabús (2000) for Argentina find a positive relationship between RPV and different measures of inflation volatility. This result holds for stable economies, as has been shown for US by Chang and Cheng (2000), and as we will show in this paper for Spain.

In short, there is a consensus on the positive correlation between inflation and RPV, but not on which factor is generating this correlation. This paper presents new evidence on this relationship, trying to see if the mechanisms that are causing it differ depending on the inflationary history of the economy analyzed. In order to address this, we study two economies with very different inflationary experiences: Spain, for the 1985-2001 period, and Argentina, for the 1960-1991 period. The first economy has been historically stable in the last fifty years, especially during the period studied in this paper, in which the monthly inflation rate oscillated in a narrow range between zero and $2 \%$. Argentina, on the contrary, shows a very rich inflationary history: in the last forty years its monthly inflation rate has fluctuated between deflation and hyperinflation.

The empirical results obtained in this paper indicate that the relationship between inflation and RPV changes in extreme inflation; in fact RPV exploded for the hyperinflation period in Argentina. For both countries inflation volatility and unexpected inflation increase RPV, although this result must be interpreted in a different way in each case, as we shall see later. On the contrary, expected inflation positively affects RPV in Argentina but is never significant in the case of Spain, denoting that inflation expectations play different roles in explaining the non-neutrality of inflation depending on the macroeconomic environment. Moreover, the inflation-RPV correlation exhibits significant structural changes across the different inflationary regimes, which verifies that 
determinants of RPV, and their relevance, are different at different inflation levels.

The remainder of the paper is organized as follows. The next section presents the main variables used in our analysis and the empirical methodology followed. Section 3 explains the method applied in order to determine the inflation regimes for each country. In section 4 we specify the main features of the data used. In section 5 we give a brief description of the statistics, and we report the results concerning the inflation-RPV relationship, as well as the results referring to the structural change observed in this relationship. Finally, section 6 concludes.

\section{Definition of variables and empirical methodology}

\subsection{Definition of variables}

Our study is based on the monthly inflation rate, which is used to define different measures of inflation volatility and RPV. Moreover, the inflation rate is separated into expected and unexpected inflation using a forecast equation of inflation.

On the one hand, for inflation volatility, three variables have been defined:

$$
\begin{aligned}
& D I N_{t}=I N_{t}-I N_{t-1} \\
& A B D I N_{t}=\left|I N_{t}-I N_{t-1}\right| \\
& \operatorname{VARIN}_{t}=\left|I N_{t}-(1 / 7) * \sum_{i=-3}^{3} I N_{t-i}\right|
\end{aligned}
$$

where $I N_{\dagger}$ is the inflation rate at time t. As it can be seen, DIN is the difference between the inflation rates of two consecutive months, ABDIN is the absolute value of DIN, and VARIN is a centred moving average of seven months of inflation. VARIN tries to capture transitory deviations of current inflation from a 
certain inflationary environment. In order to choose the lags included in VARIN, we defined the variable with three, four until twelve lags, we ran the regression specified in equation (7), and we compared the $\mathrm{R}^{2}$ and the significance of the explanatory variables obtained in each estimation. As the results were very similar for all of them, we included the minimum number of lags, given the fluctuations observed for inflation in Argentina. ${ }^{3}$

RPV is a measure of the non-uniformity of the variations of individual prices, relative to the average inflation rate. It is obtained in quadratic terms, using the weighted sum of the monthly inflation rate of individual prices. RPV can be defined as follows:

$$
R P V_{t}=\sum_{i} w_{i t}\left(I N_{i t}-I N_{t}\right)^{2}
$$

where $\mathrm{w}_{\text {it }}$ denotes the weight of price $\mathrm{i}$ in the price index, $I \mathrm{~N}_{i t}$ the inflation rate of price $\mathrm{i}$ and $\mathrm{IN} \mathrm{N}_{\dagger}$ the general inflation rate at time t. ${ }^{4}$

On the other hand, expected inflation (INE) is the inflation rate forecasted by the agents for the current period, and is estimated by means of the ARMA model that fits the "best forecast" of inflation. The ARMA structure has been selected according to the Akaike-Schwarz criterion -the estimation with the lowest value of both tests. The results suggest an AR(1) model for Argentina, and an $\operatorname{ARMA}(10,10)$ model for Spain. From our point of view these results are plausible, in the sense that in a stable economy like Spain agents could use long-run information to forecast current inflation, while in an unstable and changing environment like Argentina only short-run information should be useful. Finally, unexpected inflation (INO) is the forecasting error, and can be defined as the difference between current and expected inflation (INO=ININE). 


\subsection{Empirical methodology}

As was stated in the introduction, the goal of this paper is to analyze the links between inflation and RPV. Firstly, in order to study the effects of the inflation rate and inflation volatility on RPV, a set of equations is estimated:

$$
\begin{aligned}
& R P V_{t}=a+b_{1} I N_{t}+b_{2} D I N_{t}+e_{t} \\
& R P V_{t}=a+b_{1} I N_{t}+b_{3} \text { ABDIN }_{t}+e_{t} \\
& R P V_{t}=a+b_{1} I N_{t}+b_{4} \operatorname{VARIN}_{t}+e_{t}
\end{aligned}
$$

According to the results obtained in previous contributions (see references in the introduction), the inflation rate and inflation volatility affect RPV positively, therefore $b_{1}, b_{2}, b_{3}$ and $b_{4}$ are expected to be positive.

As far as expected and unexpected inflation is concerned, the following equation is estimated:

$$
R P V_{t}=a+b_{5} I N E_{t}+b_{6} I N O_{t}+e_{t}
$$

In this case, there is neither theoretical nor empirical consensus on their effects on inflation. The sign and the significance of the coefficients can be interpreted as evidence in favour of the menu costs model -if $b_{5}$ is positive and significant- or the signal extraction model -if $b_{6}$ is positive and significant.

Moreover, both models predict that RPV is affected by the magnitude of INE -the menu costs model- and INO -the signal extraction model- irrespective of the sign of both variables. In order to test this, equation (9) includes the absolute value of expected and unexpected inflation (ABINE and ABINO respectively):

$$
R P V_{t}=a+b_{7} A B I N E_{t}+b_{8} A B I N O_{t}+e_{t}
$$

\section{Inflationary regimes classification}

This section classifies the different periods of inflation in several regimes. For Argentina, following a version of the criterion suggested by Leijonhufvud 
(1990) for high inflation economies, we have distinguished four regimes: moderate inflation when the monthly inflation rate is lower than $1 \%-2 \%$, high inflation for the $2 \%-10 \%$ range, very high inflation for the $10 \%-50 \%$ range, and hyperinflation for values beyond $50 \%$.

The methodology to determine such regimes is based on a procedure that divides the total period into different sub-periods of inflation. ${ }^{5} \mathrm{~A}$ "smoothed-out" series from the original series of inflation is obtained as follows:

$$
S I N_{t}=\left\{\left[\frac{P I_{t}}{(1 / 12) \sum_{i=1}^{12} P I_{t-i}}\right]^{1 / 6}-1\right\} * 100
$$

where SIN is the "smoothed-out" series of monthly inflation rate and $\mathrm{Pl}_{t}$ is the monthly price index at period t. Discontinuities are detected in this series when variations of the "smoothed-out" inflation are larger than three standard deviations from the moving average of inflation, as follows:

$$
\operatorname{SDESVIN~}_{t-1, t-12}=\left[\frac{\sum_{1}^{12}\left(\operatorname{SIN}_{t-1}-\operatorname{MAVIN}_{t-1, t-12}\right)^{2}}{12}\right]^{1 / 2}
$$

where SDESVIN is the standard deviation of the moving average of inflation, and MAVIN is the yearly moving average of inflation rate for the twelve months previous to the discontinuity. Thus, this procedure captures only persistent changes, disregarding transitory variations in inflation levels.

The next step is to detect changes in the regime of inflation if the following conditions are fulfilled: 1) $\mathrm{SIN}_{t}>$ MAVIN $\mathrm{N}_{t-1, t-12}+3 \mathrm{SDESVIN}_{t-1, t-12,}$ 2) the discontinuity holds for three or more consecutive months, and 3) the average inflation rates between two periods separated by such discontinuity are significantly different, which is checked by a simple test of difference of means. 
When discontinuities are detected, the months including the "critical points" that fulfil these conditions must be identified in the original inflation rate series. Finally, once the periods of inflation are obtained, they are grouped in different regimes.

According to the aforementioned methodology, in Argentina each regime contains the following periods:

\section{Table 2}

Following the same criterion, for Spain the whole period is classified as moderate inflation -the test of difference of means was not significant in any case. However, for a low inflation country like Spain, some changes in the criterion must be made. In fact, sustained changes of the inflation level can be observed at the beginning of 1992, when the condition $\mathrm{SIN}_{t}>\mathrm{MAVIN} \mathrm{N}_{-1, \mathrm{t}-12}+$ SDESVIN $N_{-1, t-12}$ was fulfilled. In order to consider the change in inflation in 1992, the total period has been divided into two periods, high and low inflation, for the September 1985-March 1992 and April 1992-December 2001 periods respectively.

Once the inflationary regimes were determined, we have looked for the most significant breaks in the inflation rate history for both countries. According to our methodology these breaks are: February 1975 for Argentina and March 1992 for Spain. Finally, the total period has been divided into two sub-periods. ${ }^{6}$

\section{Data}

The analysis is based on monthly data. For each country the price index available at the highest degree of disaggregation has been chosen, which is an advantage in order to calculate RPV.7 According to this criterion, we have used the Wholesale Price Index (WPI) for Argentina and the Consumer Price Index (CPI) for Spain. 
As far as the Argentina price series is concerned, they have been drawn from the statistical bulletins of the Instituto Nacional de Estadísticas y Censos, covering the period January 1960-February 1991. At the three-digit level of disaggregation in the International Standard Industrial Classification, we use 87 individual prices for the January 1960-June 1984 period and 64 for the July 1984-February 1991 period -the structure of WPI in Argentina changed in July 1984.

For the Spanish case, the data cover the period September 1985December 2001, and have been drawn from the Instituto Nacional de Estadística. We have used 57 categories of the CPI.

The methodology for the collection of data differs for both countries. In Spain most of the price data are collected between the $1^{\text {st }}$ and the $22^{\text {nd }}$ day of each month. This methodology can generate a spurious correlation between RPV and inflation in a high inflation context, but not under price stability. ${ }^{8}$ Fortunately, in our high inflation case (Argentina), most prices -the prices of industrial and imported products'- are collected the same day of each month (the $15^{\text {th }}$ ), or are sampled as a monthly average from daily (or nearly daily) information -the prices of agricultural products. Hence, for Argentina, correlation between RPV and inflation should not be "contaminated" by the methodology of price collection.

As said, for both countries monthly data are used. For Argentina, as we have chosen WPI, there are no seasonality problems, because most prices, and especially the prices of industrial and imported products, do not present a seasonal component. On the contrary, for the Spanish case, CPI presents an important seasonal component. In order to remove this, an X-12 ARIMA method is applied. Thus, all the estimation results presented in the paper refer 
to non-seasonal variables for Argentina and seasonally adjusted variables for Spain.

\section{Results}

\subsection{Preliminary analysis}

The two countries studied in this paper show very different inflationary experiences. On the one hand, Spain is a stable economy, with a monthly inflation rate ranging between zero and $2 \%$ approximately. On the other hand, Argentina is a very unstable economy, with sundry inflationary episodes, going from the moderate inflation of the sixties to the extreme inflation periods of the late eighties (see Figures 1 and 2, for Spain and Argentina respectively). Nevertheless, both economies share a common pattern: higher inflation is associated with higher RPV, a relationship which is even more evident for Argentina.

\section{Figure 1}

\section{Figure 2}

For the Spanish economy, as was stated in section 3, two slightly different periods of high and low inflation can be distinguished: September 1985-March 1992 and April 1992-December 2001 respectively. Both inflation and RPV are lower in the second period. In Argentina, RPV is clearly increasing in inflation, in particular when the inflation rate increases suddenly. This is verified in the inflationary accelerations of 1962, 1975-76, 1985, and, especially, in the hyperinflations of 1989-1990. Indeed, RPV increases strongly in these cases, and reaches the highest values in the months of highest inflation. The months of hyperinflation seem to show a collapse of the price system, which implies evidence in favour of the hypothesis of non-neutrality of inflation.

There are two cases in which price variability decreases, denoting a coordination in the individual price adjustments. 
On the one hand, periods with gradual increases in inflation -for example in Argentina during the 1981-85 period. This evidence seems to be consistent with the intuition that abrupt changes of the inflation rate are required to increase RPV. High inflation volatility should increase the range between prices that adjust jointly with the general inflation and those that are indexed taking into account past values of the inflation rate. In short, the lack of synchronization in price adjustments increases RPV. On the contrary, even at high levels, a gradual increase in inflation would allow the agents to adapt to it, perhaps by means of indexation mechanisms, which may avoid staggering in price adjustments and therefore, even when inflation is increasing, RPV will be decreasing.

On the other hand, the second case refers to periods of stability in which RPV remains at very low levels, for example in the Spanish lower inflation period and during the sixties in Argentina. ${ }^{10}$

In short, higher inflation seems to be related to a more volatile and less predictable inflation rate, and to a higher RPV: the behaviour of relative prices and inflation changes at different inflation levels. This can be checked by examining the average values of these variables for each inflationary regime (see Table 3). For all cases RPV is, on average, systematically higher at higher inflation, especially in Argentina. These results show an interesting difference from previous findings. Firstly, unlike Van Hoomissen (1988) for Israel, Palerm (1991) for Mexico and Tommasi (1993) for Argentina, we find a non-concave relationship between RPV and inflation. Moreover, price dispersion explodes in extreme inflation, therefore there is no evidence of unifying forces of price revisions at hyperinflation. This can be due to the high volatility and inflationary surprises verified in these situations. Indeed, inflation volatility (ABDIN and 
VARIN) and unexpected inflation increase systematically with the level of inflation, and particularly at hyperinflation.

\section{Table 3}

\subsection{The inflation-relative price relationship: the regression analysis}

There are some issues to point out before running the regressions.

Firstly, stationarity of the series has been checked by means of the ADF test, ${ }^{11}$ for the total period and for the lower and higher inflation periods. It was applied to the original series in Argentina, and to the seasonally adjusted series in the case of Spain. In all cases we found that the series are stationary, except for Spanish RPV when the whole period is considered. In order to deal with this result, we include lags of RPV in the estimations, as is shown in Table 5. In turn, as the ADF test results show the presence of a deterministic trend in Spanish RPV, for the total and lower inflation periods, a trend term has been included in the respective estimations.

In second place, for Argentina the White test shows the presence of heteroskedasticity in some regressions. This problem has been solved using the White heteroskedasticity-consistent variances and standard errors; nevertheless, the results concerning the significance of the regressors did not change.

Thirdly, in order to tackle autocorrelation in the residuals, we have included lags of the endogenous variable in those estimations where they are required. However, the Breusch-Godfrey (BG) test shows that for some estimations the introduction of lags is not enough to remove autocorrelation. ${ }^{12}$ Nevertheless, the BG test results are very sensitive to the number of lags selected, so that the evidence of autocorrelation problems is not conclusive (see footnotes in Tables 4 and 5). 
In fourth place, multicollinearity problems can appear in estimations including inflation rate and inflation volatility measures, because both variables are closely related. As the correlation between explanatory variables can help us to understand the relevance of this problem, we have calculated the correlation coefficient, obtaining that only for two cases is it bounded between 0.50 and 0.75 -the correlation between IN and DIN for Spain and between IN and VARIN for Argentina. Therefore, in these cases, the results must be taken cautiously.

For both countries we carry out three kinds of estimations: for the total period, and for the lower and higher inflation periods. Recall that, for Argentina, the lower inflation period goes from January 1960 to January 1975, and the higher one from February 1975 to February 1991. For Spain the higher inflation period covers the September 1985-March 1992 period, and the lower one the April 1992-December 2001 period.

\section{Table 4}

\section{Table 5}

Tables 4 and 5 present the results of the regressions for equations (5) to (9). In contrast to previous literature, we offer comparative evidence from different inflationary experiences. It can be seen that there are interesting differences between the two countries at different inflation levels. In Argentina, for all regressions $\mathrm{R}^{2}$ coefficients and the significance of the explanatory variables are higher in the higher inflation period. On the contrary, for the Spanish case, $\mathrm{R}^{2}$ is generally higher in the lower inflation period, which is due to the significance of the negative trend; in addition to this, the inflation rate is significant only for the total period. These results suggest the existence of structural changes in the inflation-RPV relationship for both countries across different inflation regimes, as we will test in the next sub-section. 
There are also some similarities between the two countries. Firstly, as has been shown in previous literature, inflation volatility affects RPV positively. ${ }^{13}$ VARIN appears to be the best volatility measure to explain RPV, suggesting that changes in inflationary environment, rather than transitory variations in the inflation rate, affect RPV.

Secondly, regressions including both expected and unexpected inflation indicate that the latter is generally significant, and with the expected sign, except for the Spanish lower inflation period. Moreover, ABINO is also significant, thereby not only unexpected inflation but its magnitude increase RPV. Thus, inflationary surprise seems to be a relevant factor in order to explain RPV, regardless of the average inflation rate, as has been obtained for other countries. However, from our point of view, the interpretation of these results must be different in each case. In this sense, they can support the signal extraction approach in the Spanish higher inflation case, but they seem to be related to high economic instability in the chronic Argentine high inflation, and especially in extreme inflation. On the contrary, results concerning expected inflation are different for each country. While in Argentina it affects RPV positively, it is never significant in Spain. This difference suggests that inflation expectations play different roles, in order to explain the non-neutrality of inflation, depending on the macroeconomic context.

It seems that our results suggest that the signal extraction model is suitable only in stable economies, like Spain, implying that only inflation surprise is not neutral. But it does not work in unstable economies, like Argentina, where expected inflation increases RPV as well. Nonetheless, in our opinion, this finding does not support the menu costs model in inflationary economies, because at high inflation adjustment costs are trivial. The fact that both expected and unexpected inflation are significant in Argentina seems to 
indicate the presence of important problems in order to forecast current inflation, as well as high macroeconomic volatility is making increasingly complex the price decisions for economic agents. ${ }^{14}$ In fact, RPV exploded in the Argentine hyperinflation, which suggests that there are no successful mechanisms to avoid the impact of inflation on relative prices, like indexation or a "good" model to make expectations on current inflation. In other words, our analysis suggests that agents cannot find an adaptive mechanism to minimize the inflationary surprise associated with those episodes.

In short, our findings are similar to those obtained in previous literature, in the sense that they suggest clearly that inflation is non-neutral, but they go further in that they suggest that non-neutrality is more evident at higher inflation, and particularly in extreme inflation. Moreover, the plausible causes for non-neutrality are different depending on the macroeconomic environment: for stable economies the explanations based on the signal extraction or the menu costs models can be meaningful, but they do not seem to be suitable for unstable economies. Finally, our results appear to support the signal extraction model rather than the menu costs approach, as has been shown for other stable economies like Germany -see Miszler and Nautz (2004).

\subsection{Structural change}

The different results obtained in the estimations for the whole period and for lower and high inflation periods suggest that there can be structural changes in the RPV-inflation relationship. Firstly, applying the recursive residual estimation and the CUSUM test, we check for both countries if there is one or more structural changes. Once the breaks have been detected, the Chow test is applied in order to verify the results. Finally, we compare if the breaks detected in the RPV-inflation relationship with this methodology are the same found by means of the method used in section 3 to delimitate the inflationary 
regimes. We check for all cases that there is a structural change in that relationship when there is a change in the inflationary regime -recall that the most relevant breaks that we found were February 1975 for Argentina and March 1992 for Spain- as is shown in Table 6.

\section{Table 6}

As can be seen in Table 6, structural changes are significant at $1 \%$ level of confidence, which seems to prove our hypothesis that the effects of inflation, its volatility and the components of expected and unexpected inflation are different at low and high inflation. In fact, as has been mentioned, in general these changes are associated with higher significance of the explanatory variables, which supports the idea that the non-neutrality of inflation is more evident with higher economic instability.

In conclusion, the structural change seems to support the hypothesis that the determinants of RPV -and their relevance- change at different inflation levels, even in a narrow range of inflation, as in the Spanish case.

\section{Concluding remarks}

This paper analyzes the relationship between inflation and relative prices for two economies with very different inflationary history: Argentina and Spain. While the former shows high price instability, the latter is characterized by a low and stable inflation. Our findings support the hypothesis of the non-neutrality of inflation, which is more evident at high inflation, and particularly at extreme inflation (for example, in both Argentine hyperinflations). Moreover, there is a non-concave relationship between RPV and inflation in Argentina, denoting that inflation affects RPV more than proportionally beyond a certain threshold of inflation.

The main determinants of RPV are inflation, inflation volatility and unexpected inflation. ${ }^{15}$ VARIN is the best inflation volatility variable to explain 
RPV, which suggests that changes in the inflationary environment have a greater effect than transitory deviations of the inflation rate from its trend on relative prices. Our results can support the signal extraction approach in low inflation; however, in extreme inflation they seem to show that there are notable problems in forecasting the current inflation rate, as well as in taking price decisions.

Comparing the results for the two economies we find an interesting difference: expected inflation is only significant in the high inflation country (Argentina). Apparently, this result neither supports the menu costs approach there are no nominal rigidities in high inflation- nor the signal extraction approach. Instead, this latter approach seems to be suitable for Spanish results, where only unexpected inflation is, in general, significant.

Finally, the inflation-RPV relationship exhibits significant structural changes across the different inflationary regimes, which seems to prove the hypothesis that the determinants of RPV, and their relevance, are different at different inflation levels.

This research can be developed in several directions. A first extension is to include new economies in the sample, in order to check if our results hold. Another extension is to analyze the role of higher moments of the price change distribution, like skewness and kurtosis. ${ }^{16}$ This extension could determine if the inflation-RPV relationship is influenced by them, as suggested by Bryan and Cecchetti (1999). Finally, an interesting branch of research could study if the causality of the relationship changes with the regime of inflation.

\section{References}

Aarstol, M. (1999): "Inflation, Inflation Uncertainty, and Relative Price Variability", Southern Economic Journal, 66 (2), pp. 414-423.

Amano, R.A. and Macklem, R. (1997): "Menu Costs, Relative Prices, and Inflation: Evidence for Canada", Bank of Canada, Working Paper 97-14. 
Assarsson, B. (2004): "Inflation and Relative-Price Changes in the Swedish Economy", Sveriges Riksbank Economic Review, 3, pp. 43-62.

Aucremanne, L., Brys, G., Hubert, M., Rousseeuw, P.J. and Struyf, A. (2002): "Inflation, Relative Prices and Nominal Rigidities", National Bank of Belgium, Working Paper 20.

Ball, L. and Mankiw, N.G. (1995): "Relative-Price Changes as Aggregate Supply Shocks", Quarterly Journal of Economics, 110 (1), pp. 161-193.

Blejer, M. (1979): "Inflation Variability in Latin America: A Note on the Time-Series Evidence", Economics Letters, 2 (4), pp. 337-341.

Blejer, M. and Leiderman, L. (1982): "Inflation and Relative Price Variability in the Open Economy", European Economic Review, 18, April, pp. 387-402.

Bomberger, W.A. and Makinen, G.E. (1993): "Inflation and Relative Price Variability: Parks' Study Reexamined", Journal of Money, Credit and Banking, 25 (4), pp. 854-861.

Bryan, M.F. and Cecchetti, S.G. (1999): "Inflation and the Distribution of Price Changes", Review of Economics and Statistics, 81 (2), pp. 188-196.

Caglayan, M. and Filiztekin, A. (2003): "Nonlinear Impact of Inflation on Relative Price Variability", Economics Letters, 79 (2), pp. 213-218.

Caraballo, M.A. and Usabiaga, C. (2004a): "Análisis de la Estructura de la Inflación de las Regiones Españolas: La Metodología de Ball y Mankiw", Investigaciones Regionales, 5, pp. 63-86.

Caraballo, M.A. and Usabiaga, C. (2004b): "Inflation and Relative Prices. Empirical Evidence for the Spanish Economy", Problems and Perspectives in Management, Chapter 1: Macroeconomic Processes and Regional Economies Management, 3, pp. 59-71.

Chang, E.C. and Cheng, J.W. (2000): "Further Evidence on the Variability of Inflation and Relative Price Variability", Economics Letters, 66 (1), pp. 71-77.

Dabús, C. (1993): Inflación y Precios Relativos: Estudio del Caso Argentino, Doctoral Dissertation, Universidad Nacional del Sur (Argentina).

Dabús, C. (2000): "Inflationary Regimes and Relative Price Variability: Evidence from Argentina", Journal of Development Economics, 62 (2), pp. 535547.

Dazinger, L. (1987): "Inflation, Fixed Cost of Price Adjustment, and the Measurement of Relative Price Variability: Theory and Evidence", American Economic Review, 77 (4), pp. 704-713.

Debelle, G. and Lamont, O. (1997): "Relative Price Variability and Inflation: Evidence from US Cities", Journal of Political Economy, 105 (1), pp. 132153.

Domberger, S. (1987): "Relative Price Variability and Inflation: a Disaggregated Analysis", Journal of Political Economy, 95 (3), pp. 547-566.

Döpke, J. and Pierdzioch, C. (2003): "Inflation and Skewness of the Distribution of Relative Price Changes: Empirical Evidence for Germany", Jahrbücher für Nationalökonomie und Statistik, 223 (2), pp. 136-159.

Fielding, D. and Mizen, P. (2000): "Relative Price Variability and Inflation in Europe", Economica, 67 (265), pp. 57-78.

Fischer, S. (1981): "Relative Shocks, Relative Price Variability, and Inflation", Brookings Papers on Economic Activity, 2, pp. 381-431.

Fischer, S. (1982): "Relative Price Variability and Inflation in the United States and Germany", European Economic Review, 18 (1), pp. 171-196.

Hall, S. and Yates, A. (1998): "Are There Downward Nominal Rigidities in Product Markets?", Bank of England, Working Paper Series, 80. 
Inclan, C. and Tiao, G.C. (1994): "Use of Cumulative Sums of Squares for Retrospective Detection of Changes of Variance", Journal of the American Statistical Association, 89 (247), pp. 913-923.

Lach, S. and Tsiddon, D. (1992): "The Behaviour of Prices and Inflation: An Empirical Analysis of Disaggregated Price Data", Journal of Political Economy, 100 (2), pp. 349-389.

Leijonhufvud, A. (1990): Extreme Monetary Instability: High Inflation, Lecture, University of Hoheneim (Germany), mimeo.

Logue, D.E. and Willet, T.D. (1976): "A Note on the Relation between the Rate and Variability of Inflation", Economica, 43 (170), pp. 151-157.

Mills, F. (1927): The Behavior of Prices, Arno, New York.

Miszler, J. and Nautz, D. (2004): "Inflation and Relative Price Variability in a Low Inflation Country: Empirical Evidence from Germany", mimeo.

Moura, A. and Kadota, D.K. (1982): "Inflaçao e Preços Relativos: Medidas de Dispersao", Pesquisa e Planejamento Económico, 12 (1), pp. 1-21.

Nath, H.K. (2004): "Relative Importance of Sectoral and Aggregate Sources of Price Changes", Applied Economics, 36 (16), pp. 1781-1797.

Palerm, A. (1991): "Market Structure and Price Flexibility", Journal of Development Economics, 36 (1), pp. 37-54.

Parks, R.W. (1978): "Inflation and Relative Price Variability", Journal of Political Economy, 86 (1), pp. 79-95.

Parsley, D.C. (1996): "Inflation and Relative Price Variability in the Short and Long Run: New Evidence from the United States", Journal of Money, Credit and Banking, 28 (3), pp. 323-342.

Sansó, A., Aragó, V. and Carrion-i-Silvestre, J.L. (2004): "Testing for Changes in the Unconditional Variance of Financial Time Series", Revista de Economía Financiera (forthcoming).

Silver, M. and Ioannidis, C. (2001): "Intercountry Differences in the Relationship between Relative Price Variability and Average Prices", Journal of Political Economy, 109 (2), pp. 355-374.

Tang, D. and Wang, P. (1993): "On Relative Price Variability and Hyperinflation," Economics Letters, 42 (2-3), pp. 209-214.

Tommasi, M. (1993): "Inflation and Relative Prices: Evidence from Argentina", in Sheshinski E. and Weiss, Y. (1993) (Eds.): Optimal Pricing, Inflation and Cost of Price Adjustment, MIT Press, Cambridge (Mass.), pp. 487-513.

Van Hoomissen, T. (1988): "Price Dispersion and Inflation: Evidence from Israel", Journal of Political Economy, 96 (6), pp. 1303-1314.

Vining, D.R. and Elwertowski, T.C. (1976): "The Relationship between Relative Prices and General Price Level", American Economic Review, 66 (4), pp. 699-708.

\section{Acknowledgements}

We acknowledge the financial support from Centro de Estudios Andaluces (Project ECO 17), as well as the useful comments from the participants in the Latin American Meeting of the Econometric Society (2004), members of the Macroeconomics Group (2004) of Centro de Estudios Andaluces, Juan F. 
Jimeno and anonymous referees of Centro de Estudios Andaluces (working paper E2004/71) and Applied Economics. The remaining errors are ours.

\section{Notes}

(1) Likewise, an important strand of the literature focuses on intramarket RPV. This variable can be defined as the standard deviation of relative price changes of a given product across stores around the average inflation rate of that product. A number of authors have found evidence supporting a positive correlation between intramarket RPV and inflation: Domberger (1987) for the United Kingdom, Lach and Tsiddon (1992) for Israel, Amano and Macklem (1997) for Canada, and Parsley (1996) for some cities of United States (US). However, when economies are experiencing very high inflation rates, intramarket RPV can decrease when inflation increases, as has been shown by Dazinger (1987) and Van Hoomissen (1988) for Israel, Tommasi (1993) for Argentina and Caglayan and Filiztekin (2003) for Turkey.

(2) Nevertheless, Fischer $(1981,1982)$ and Bomberger and Makinen (1993) assert that the relationship between inflation and RPV found for US is dominated by energy and food price shocks.

(3) In fact, the key factor is to determine how many months "around" the current inflation make a homogeneous period of inflation. As has been said, for Argentina we select only three months, because given the great changes observed in its inflation rate, adding more lags could lead us to include months belonging to different inflationary contexts, and therefore there would be a risk of overestimating this measure. For Spain this problem is not so important, but as the results of the estimations are similar with three or more lags, we have chosen the same number of lags as for Argentina in order to compare the results. 
(4) For Argentina a slight variation of equation (4) is used, because, as was stated in Dabús (1993), equation (4) is not the best measure for RPV in high inflation economies. In this context, the estimation of the coefficient of variation of the price change distribution is required, instead of the simple variance, because at high inflation the latter is spuriously correlated with the mean of the distribution -the inflation rate. To avoid this problem, RPV for Argentina is defined as follows:

$$
R P V_{t}=\frac{\sum_{i} w_{i t}\left(I N_{i t}-I N_{t}\right)^{2}}{\left(1+I N_{t}\right)^{2}}
$$

(5) For a more detailed explanation of this methodology see Dabús (1993). An alternative approach to delimitate inflationary regimes could be based on changes in the variance of the inflation series, for example using the ICSS algorithm developed by Inclan and Tiao (1994) and Sansó et al. (2004). In further research we intend to compare both approaches for data from several countries.

(6) Given the size of each sub-period for Argentina, it is not possible to develop the analysis for each one.

(7) The degree of disaggregation can affect the estimations; therefore, in order to compare the results for both countries, homogeneity in the degree of disaggregation is required, otherwise different results can be obtained due just to the different kind of data used. Another distortion can be introduced in the results by the fact that we are using two different price indexes. On the one hand, this problem is not avoidable because the same price index, with a similar degree of disaggregation, is not available for both countries. On the other hand, Caraballo and Usabiaga (2004b) carry out a similar study for Spain using two price indexes, Producer Price Index (PPI) and Consumer Price Index (CPI), with a similar degree of disaggregation (25 categories for PPI and 33 
categories for $\mathrm{CPI}$ ), and there are not remarkable changes in the estimations. Moreover, the estimations using CPI with different degree of disaggregation yield more relevant changes. Taking these arguments into account, it seems to be more appropriate to use different price indexes with a similar degree of disaggregation.

(8) For example, if two prices are always equal, and every month one of those prices is sampled the first day and the other the last day, the true variability of relative prices is zero. At low inflation a low RPV should be detected, but at high inflation a higher variability will be detected, which would be just the consequence of the periodicity of price collection.

(9) Data include 77 industrial and imported good prices, from a total of 87, for the 1960-1984 period, and 55, from a total of 64, for the 1984-1991 period.

(10) In other countries different results have been obtained. For instance, for Turkey, during the 1948-1997 period, Caglayan and Filiztekin (2003) find a lower effect of inflation on relative prices during the higher inflationary period.

(11) In order to select the number of lags, the Akaike criterion has been applied.

(12) This result is observed especially in high inflation periods. It denotes that there are variables affecting RPV that have not been included in our equations, in particular real variables related to high economic volatility, like changes in real exchange rate and real wages -see, for example, Fischer (1981) and Dabús (1993) for further details.

(13) As we stated in the introduction, this result has been obtained both for inflationary economies -see Logue and Willet (1976), Blejer (1979), Moura and Kadota (1982) and Dabús (2000)- and stable economies -see Chang and Cheng (2000). 
(14) The same result was obtained for the Chinese hyperinflation (1946-1949) see Tang and Wang (1993).

(15) Recent papers show that sectoral factors have an important impact on RPV as well -see, for example, Nath (2004).

(16) In general, a positive association inflation-skewness is supported by the data -see, for example, Ball and Mankiw (1995) for the US, Amano and Macklen (1997) for Canada, Hall and Yates (1998) for the United Kingdom, Aucremanne et al. (2002) for Belgium, Döpke and Pierdzioch (2003) for Germany, Assarsson (2004) for Sweden and Caraballo and Usabiaga (2004a, 2004b) for Spain. 
Figures and tables

Figure 1. Monthly inflation rate and relative price variability. Spain

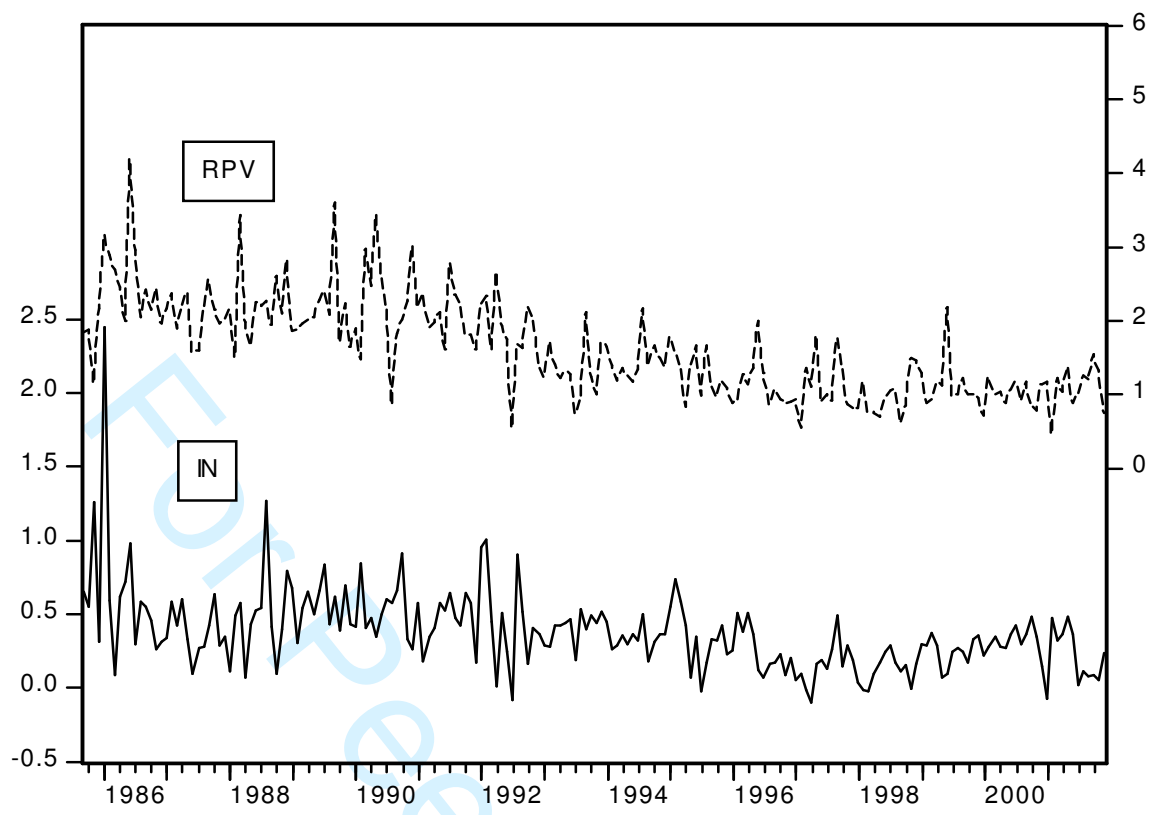

Figure 2. Monthly inflation rate and relative price variability. Argentina

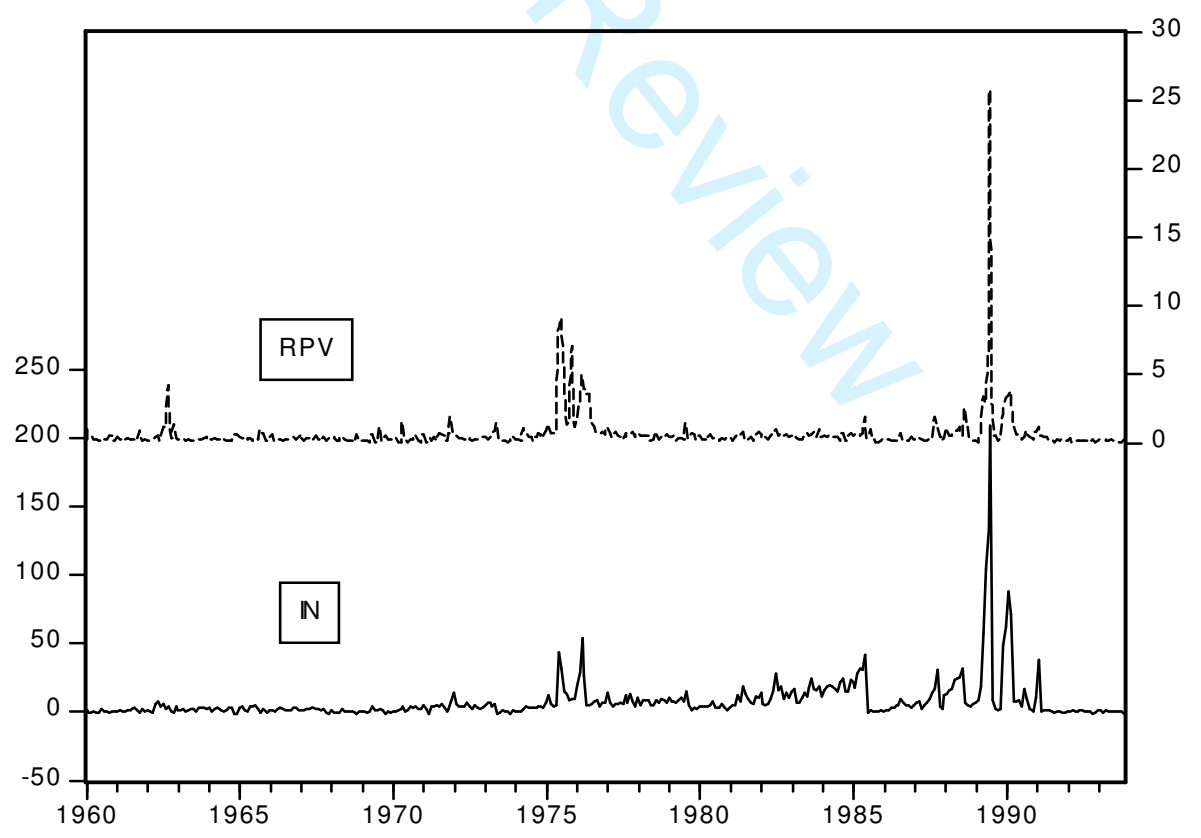


Table 1. Empirical evidence

\begin{tabular}{|c|l|l|}
\hline Author & \multicolumn{1}{|c|}{ Data } & \multicolumn{1}{c|}{ Results } \\
\hline $\begin{array}{c}\text { Parks } \\
\text { (1978) }\end{array}$ & US, 1930-1975 & RPV increases mainly with unexpected inflation \\
\hline $\begin{array}{c}\text { Fischer } \\
(1981,1982)\end{array}$ & US, 1930-1979 & $\begin{array}{l}\text { RPV increases with expected inflation and positive } \\
\text { unexpected inflation but not with negative unexpected } \\
\text { inflation }\end{array}$ \\
\hline $\begin{array}{c}\text { Tang and } \\
\text { Wang } \\
\text { (1993) }\end{array}$ & $\begin{array}{l}\text { China, 1946-1949 } \\
\text { (hyperinflation } \\
\text { period) }\end{array}$ & $\begin{array}{l}\text { RPV increases with expected inflation as well as with the } \\
\text { absolute value of unexpected inflation }\end{array}$ \\
\hline $\begin{array}{c}\text { Aarstol } \\
\text { (1999) }\end{array}$ & US, 1947-1997 & $\begin{array}{l}\text { Expected inflation and unexpected inflation, in particular } \\
\text { when positive, are all positively related to RPV }\end{array}$ \\
\hline $\begin{array}{c}\text { Silver and } \\
\text { loannidis } \\
\text { (2001) }\end{array}$ & $\begin{array}{l}\text { Nine European } \\
\text { countries, }\end{array}$ & $\begin{array}{l}\text { Coefficients for unexpected inflation are generally } \\
\text { statistically significant and negative. When expected } \\
\text { inflation is significant, the response of RPV to its changes is } \\
\text { greater where expected inflation is rising }\end{array}$ \\
\hline $\begin{array}{c}\text { Miszler and } \\
\text { Nautz } \\
\text { (2004) }\end{array}$ & $\begin{array}{l}\text { Germany, } \\
1991-2003\end{array}$ & $\begin{array}{l}\text { Only unexpected inflation affects positively RPV. The } \\
\text { impact of expected inflation disappears if a credible } \\
\text { monetary policy stabilizes inflationary expectations }\end{array}$ \\
\hline
\end{tabular}

Table 2. Inflation regimes. Argentina

\begin{tabular}{|l|l|}
\hline \multicolumn{1}{|c|}{ Inflation regime } & \multicolumn{1}{|c|}{ Period } \\
\hline Moderate inflation & January 1960-April 1970 \\
\hline High inflation & May 1970-January 1975, May 1976-June 1982, July \\
& 1985-June 1987, September1988-March 1989, August \\
& 1989-November 1989, April 1990-February 1991 \\
\hline Very high inflation & $\begin{array}{l}\text { February 1975-April 1976, July 1982-June 1985, July } \\
\text { 1987-August 1988 }\end{array}$ \\
\hline Hyperinflation & April 1989-July 1989, December 1989-March 1990 \\
\hline
\end{tabular}


Table 3.A. Average values by regime of inflation. Argentina and Spain

\begin{tabular}{|c|c|c|c|c|}
\hline & Spain & & Argentino & \\
\hline $\begin{array}{l}\text { Regimes/ } \\
\text { Variables }\end{array}$ & $\begin{array}{l}\text { Higher } \\
\text { inflation } \\
\text { period } \\
\text { (1985.09- } \\
\text { 1992.03) }\end{array}$ & $\begin{array}{l}\text { Lower } \\
\text { inflation } \\
\text { period } \\
(1992.04- \\
2001.12)\end{array}$ & $\begin{array}{l}\text { Lower } \\
\text { inflation } \\
\text { period } \\
(1960.01- \\
1975.01)\end{array}$ & $\begin{array}{l}\text { Higher } \\
\text { inflation } \\
\text { period } \\
\text { (1975.02- } \\
1991.02)\end{array}$ \\
\hline IN & 0.53 & 0.27 & 1.9 & 14.3 \\
\hline ABDIN & 0.30 & 0.13 & 1.5 & 7.3 \\
\hline VARIN & 0.19 & 0.10 & 1.1 & 7.1 \\
\hline$A B I N O$ & 0.36 & 0.18 & 1.7 & 11.1 \\
\hline RPV & 2.20 & 1.17 & 0.4 & 1.0 \\
\hline
\end{tabular}

Table 3.B. Average values by regime of inflation. Argentina

\begin{tabular}{|l|c|c|c|c|c|}
\hline $\begin{array}{l}\text { Regimes/ } \\
\text { Variables }\end{array}$ & $\begin{array}{l}\text { Moderate } \\
\text { Inflation }\end{array}$ & $\begin{array}{l}\text { High } \\
\text { inflation }\end{array}$ & $\begin{array}{l}\text { Very high } \\
\text { inflation }\end{array}$ & Hyperinflation & July 1989* \\
\hline IN & 1.4 & 5.5 & 18.3 & 96.8 & 209.1 \\
\hline ABDIN & 1.3 & 4.6 & 6.4 & 36.6 & 75.6 \\
\hline VARIN & 1.0 & 4.1 & 5.9 & 43.2 & 135.2 \\
\hline ABINO & 1.2 & 2.4 & 5.9 & 10.1 & 16.7 \\
\hline RPV & 0.3 & 0.5 & 1.2 & 6.4 & 25.7 \\
\hline
\end{tabular}

* The highest inflation month of the Argentine hyperinflations. 
Table 4.A. Regression results. Argentina dependent variable: RPV, explanatory variables: volatility measures

\begin{tabular}{|c|c|c|c|c|c|}
\hline \multicolumn{6}{|c|}{ Total period: $1960.01-1991.02$} \\
\hline Regression 1 & & Regression 2 & & Regression 3 & \\
\hline$R^{2}$ & 0.60 & $R^{2}$ & 0.61 & $R^{2}$ & 0.65 \\
\hline$B G$ & 0.00 & $B G$ & 0.00 & $B G$ & 0.00 \\
\hline CONSTANT & $\begin{array}{c}0.04 \\
(0.53) \\
\end{array}$ & CONSTANT & $\begin{array}{c}0.04 \\
(0.55) \\
\end{array}$ & CONSTANT & $\begin{array}{c}0.05 \\
(0.41) \\
\end{array}$ \\
\hline IN & $\begin{array}{c}0.08 \\
(0.00)\end{array}$ & IN & $\begin{array}{c}0.07 \\
(0.00) \\
\end{array}$ & IN & $\begin{array}{c}0.05 \\
(0.00) \\
\end{array}$ \\
\hline DIN & $\begin{array}{l}-0.01 \\
(0.01)\end{array}$ & ABDIN & $\begin{array}{c}0.02 \\
(0.00)\end{array}$ & VARIN & $\begin{array}{c}0.06 \\
(0.00) \\
\end{array}$ \\
\hline \multicolumn{6}{|c|}{ Lower inflation period: $1960.01-1975.01$} \\
\hline Regression 4 & $B$ & Regression 5 & & Regression 6 & \\
\hline$R^{2}$ & 0.06 & $R^{2}$ & 0.09 & $R^{2}$ & 0.08 \\
\hline$B G$ & 0.03 & $B G$ & 0.17 & $B G$ & 0.07 \\
\hline CONSTANT & $\begin{array}{c}0.27 \\
(0.00) \\
\end{array}$ & CONSTANT & $\begin{array}{c}0.21 \\
(0.00)\end{array}$ & CONSTANT & $\begin{array}{c}0.22 \\
(0.00) \\
\end{array}$ \\
\hline IN & $\begin{array}{c}0.05 \\
(0.00) \\
\end{array}$ & $\mathrm{IN}$ & $\begin{array}{c}0.04 \\
(0.01) \\
\end{array}$ & IN & $\begin{array}{c}0.04 \\
(0.01) \\
\end{array}$ \\
\hline DIN & $\begin{array}{l}-0.00 \\
(0.91)\end{array}$ & ABDIN & $\begin{array}{c}0.06 \\
(0.01)\end{array}$ & VARIN & $\begin{array}{c}0.06 \\
(0.02) \\
\end{array}$ \\
\hline \multicolumn{6}{|c|}{ Higher inflation period: $1975.02-1991.02$} \\
\hline Regression 7 & & Regression 8 & & Regression 9 & \\
\hline$R^{2}$ & 0.62 & $R^{2}$ & 0.62 & $R^{2}$ & 0.66 \\
\hline$B G$ & 0.00 & $B G$ & 0.00 & $B G$ & 0.00 \\
\hline CONSTANT & $\begin{array}{l}-0.20 \\
(0.10)\end{array}$ & CONSTANT & $\begin{array}{l}-0.18 \\
(0.12)\end{array}$ & CONSTANT & $\begin{array}{l}-0.16 \\
(0.00)\end{array}$ \\
\hline IN & $\begin{array}{c}0.08 \\
(0.00)\end{array}$ & IN & $\begin{array}{c}0.07 \\
(0.00)\end{array}$ & IN & $\begin{array}{c}0.06 \\
(0.00)\end{array}$ \\
\hline DIN & $\begin{array}{l}-0.01 \\
(0.03)\end{array}$ & $A B D I N$ & $\begin{array}{c}0.02 \\
(0.00) \\
\end{array}$ & VARIN & $\begin{array}{c}0.04 \\
(0.00)\end{array}$ \\
\hline
\end{tabular}

Notes:

* Autocorrelation is due to the presence of outliers in the abrupt increases of inflation rate of 1975 and both hyperinflations. Fortunately, autocorrelation problems in Argentina do not obey the structure of the residuals.

* For all tables of results presented in this paper, regressions were made by means of OLS. Values in brackets refer to the p-value obtained when testing the null hypothesis that the coefficient estimated is significantly different from zero. $R^{2}$ refers to adjusted $R^{2}$. The specification test p-values reported are the BG test results for the presence of first order serial correlation. 
Table 4.B. Regression results. Argentina dependent variable: RPV, explanatory variables: expected and unexpected inflation

\begin{tabular}{|c|c|c|c|}
\hline \multicolumn{4}{|c|}{ Total period: 1960.01-1991.02 } \\
\hline Regression 1 & & Regression 2 & \\
\hline$R^{2}$ & 0.60 & $R^{2}$ & 0.55 \\
\hline$B G$ & 0.00 & $B G$ & 0.00 \\
\hline CONSTANT & $\begin{array}{c}0.07 \\
(0.27)\end{array}$ & CONSTANT & $\begin{array}{l}-0.02 \\
(0.81)\end{array}$ \\
\hline INE & $\begin{array}{c}0.08 \\
(0.00)\end{array}$ & $\mathrm{ABINE}$ & $\begin{array}{c}0.07 \\
(0.00)\end{array}$ \\
\hline INO & $\begin{array}{c}0.08 \\
(0.00)\end{array}$ & ABINO & $\begin{array}{r}0.05 \\
(0.00)\end{array}$ \\
\hline \multicolumn{4}{|c|}{ Lower inflation period: 1960.01-1975.01 } \\
\hline Regression 3 & & Regression 4 & \\
\hline$R^{2}$ & 0.06 & $R^{2}$ & 0.08 \\
\hline$B G$ & 0.00 & $B G$ & 0.00 \\
\hline CONSTANT & $\begin{array}{c}0.27 \\
(0.00)\end{array}$ & CONSTANT & $\begin{array}{r}0.18 \\
(0.00) \\
\end{array}$ \\
\hline INE & $\begin{array}{c}0.05 \\
(0.03)\end{array}$ & ABINE & $\begin{array}{c}0.03 \\
(0.18) \\
\end{array}$ \\
\hline INO & $\begin{array}{c}0.04 \\
(0.00)\end{array}$ & ABINO & $\begin{array}{c}0.09 \\
(0.00) \\
\end{array}$ \\
\hline \multicolumn{4}{|c|}{ Higher inflation period: 1975.02-1991.02 } \\
\hline Regression 5 & & Regression 6 & \\
\hline$R^{2}$ & 0.61 & $R^{2}$ & 0.56 \\
\hline$B G$ & 0.00 & $B G$ & 0.00 \\
\hline CONSTANT & $\begin{array}{l}-0.01 \\
(0.28) \\
\end{array}$ & CONSTANT & $\begin{array}{l}-0.29 \\
(0.04) \\
\end{array}$ \\
\hline INE & $\begin{array}{c}0.08 \\
(0.00)\end{array}$ & ABINE & $\begin{array}{c}0.07 \\
(0.00)\end{array}$ \\
\hline INO & $\begin{array}{c}0.08 \\
(0.00) \\
\end{array}$ & ABINO & $\begin{array}{r}0.06 \\
(0.01) \\
\end{array}$ \\
\hline
\end{tabular}


Table 5.A. Regression results. Spain dependent variable: RPV, explanatory variables: volatility measures

\begin{tabular}{|c|c|c|c|c|c|}
\hline \multicolumn{6}{|c|}{ Total period: $1985.09-2001.12$} \\
\hline Regression 1 & & Regression 2 & & Regression 3 & \\
\hline$R^{2}$ & 0.56 & $R^{2}$ & 0.56 & $R^{2}$ & 0.60 \\
\hline$B G$ & 0.02 & $B G$ & 0.01 & $B G$ & 0.09 \\
\hline CONSTANT & $\begin{array}{c}1.72 \\
(0.00) \\
\end{array}$ & CONSTANT & $\begin{array}{c}1.75 \\
(0.00) \\
\end{array}$ & CONSTANT & $\begin{array}{c}1.77 \\
(0.00) \\
\end{array}$ \\
\hline $\operatorname{RPV}(-1)$ & $\begin{array}{c}0.19 \\
(0.00)\end{array}$ & $\operatorname{RPV}(-1)$ & $\begin{array}{c}0.20 \\
(0.00)\end{array}$ & $\operatorname{RPV}(-1)$ & $\begin{array}{c}0.18 \\
(0.01)\end{array}$ \\
\hline TREND & $\begin{array}{l}-0.01 \\
(0.00)\end{array}$ & TREND & $\begin{array}{l}-0.01 \\
(0.00)\end{array}$ & TREND & $\begin{array}{l}-0.01 \\
(0.00)\end{array}$ \\
\hline IN & $\begin{array}{c}0.42 \\
(0.01)\end{array}$ & IN & $\begin{array}{c}0.26 \\
(0.06)\end{array}$ & IN & $\begin{array}{c}0.27 \\
(0.05)\end{array}$ \\
\hline DIN & $\begin{array}{l}-0.11 \\
(0.37)\end{array}$ & ABDIN & $\begin{array}{c}0.14 \\
(0.33)\end{array}$ & VARIN & $\begin{array}{c}0.47 \\
(0.03) \\
\end{array}$ \\
\hline \multicolumn{6}{|c|}{ Higher inflation period: 1985.09-1992.03 } \\
\hline Regression 4 & & Regression 5 & & Regression 6 & \\
\hline$R^{2}$ & 0.01 & $R^{2}$ & 0.01 & $R^{2}$ & 0.07 \\
\hline$B G$ & 0.09 & $B G$ & 0.07 & $B G$ & 0.29 \\
\hline CONSTANT & $\begin{array}{c}1.76 \\
(0.00)\end{array}$ & CONSTANT & $\begin{array}{c}1.83 \\
(0.00)\end{array}$ & CONSTANT & $\begin{array}{c}1.83 \\
(0.00)\end{array}$ \\
\hline $\operatorname{RPV}(-1)$ & $\begin{array}{c}0.11 \\
(0.35)\end{array}$ & $\operatorname{RPV}(-1)$ & $\begin{array}{c}0.10 \\
(0.39)\end{array}$ & $\operatorname{RPV}(-1)$ & $\begin{array}{c}0.09 \\
(0.43)\end{array}$ \\
\hline IN & $\begin{array}{c}0.39 \\
(0.13)\end{array}$ & $\mathrm{IN}$ & $\begin{array}{c}0.20 \\
(0.35)\end{array}$ & $\mathrm{IN}$ & $\begin{array}{c}0.17 \\
(0.46)\end{array}$ \\
\hline DIN & $\begin{array}{l}-0.10 \\
(0.58) \\
\end{array}$ & ABDIN & $\begin{array}{l}0.168 \\
(0.39) \\
\end{array}$ & VARIN & $\begin{array}{c}0.56 \\
(0.09) \\
\end{array}$ \\
\hline \multicolumn{6}{|c|}{ Lower inflation period: 1992.04-2001.12 } \\
\hline Regression 7 & & Regression 8 & +2 & Regression 9 & \\
\hline$R^{2}$ & 0.18 & $R^{2}$ & 0.19 & $R^{2}$ & 0.20 \\
\hline$B G$ & 0.11 & $B G$ & 0.15 & $B G$ & 0.14 \\
\hline CONSTANT & $\begin{array}{c}1.79 \\
(0.00)\end{array}$ & CONSTANT & $\begin{array}{c}1.74 \\
(0.00)\end{array}$ & CONSTANT & $\begin{array}{c}1.72 \\
(0.00)\end{array}$ \\
\hline TREND & $\begin{array}{l}-0.01 \\
(0.00)\end{array}$ & TREND & $\begin{array}{l}-0.01 \\
(0.00)\end{array}$ & TREND & $\begin{array}{l}-0.01 \\
(0.00)\end{array}$ \\
\hline IN & $\begin{array}{c}0.25 \\
(0.29) \\
\end{array}$ & IN & $\begin{array}{c}0.12 \\
(0.52) \\
\end{array}$ & IN & $\begin{array}{c}0.18 \\
(0.35) \\
\end{array}$ \\
\hline DIN & $\begin{array}{l}-0.15 \\
(0.48)\end{array}$ & ABDIN & $\begin{array}{c}0.41 \\
(0.10)\end{array}$ & VARIN & $\begin{array}{c}0.74 \\
(0.05)\end{array}$ \\
\hline
\end{tabular}

Note:

* For Tables 5A and 5B, lags of the endogenous variable were included when the unit root test indicated the presence of non-stationarity, and to deal with autocorrelation. The trend term (TREND) was included when it was significant according to that test. Following the parsimony principle we include the lowest number of lags required in each case. 
Table 5.B. Regression results. Spain dependent variable: RPV, explanatory variables: expected and unexpected inflation

\begin{tabular}{|c|c|c|c|}
\hline \multicolumn{4}{|c|}{ Total period: 1985.09-2001.12 } \\
\hline Regression 1 & & Regression 2 & \\
\hline$R^{2}$ & 0.57 & $R^{2}$ & 0.56 \\
\hline$B G$ & 0.15 & $B G$ & 0.36 \\
\hline CONSTANT & $\begin{array}{c}1.84 \\
(0.00)\end{array}$ & CONSTANT & $\begin{array}{r}1.82 \\
(0.00) \\
\end{array}$ \\
\hline$R P V(-1)$ & $\begin{array}{c}0.23 \\
(000)\end{array}$ & $\operatorname{RPV}(-1)$ & $\begin{array}{c}0.21 \\
(0.00) \\
\end{array}$ \\
\hline TREND & $\begin{array}{l}-0.00 \\
(0.00)\end{array}$ & TREND & $\begin{array}{l}-0.01 \\
(0.00) \\
\end{array}$ \\
\hline INE & $\begin{array}{l}-0.02 \\
(0.84)\end{array}$ & ABINE & $\begin{array}{l}-0.07 \\
(0.57) \\
\end{array}$ \\
\hline INO & $\begin{array}{c}0.37 \\
(0.00)\end{array}$ & ABINO & $\begin{array}{c}0.51 \\
(0.00) \\
\end{array}$ \\
\hline \multicolumn{4}{|c|}{ Higher inflation period: 1985.09-1992.03 } \\
\hline Regression 3 & & Regression 4 & \\
\hline$R^{2}$ & 0.04 & $R^{2}$ & 0.02 \\
\hline$B G$ & 0.21 & $B G$ & 0.39 \\
\hline CONSTANT & $\begin{array}{c}2.13 \\
(0.00) \\
\end{array}$ & CONSTANT & $\begin{array}{l}2.05 \\
(0.0) \\
\end{array}$ \\
\hline INE & $\begin{array}{c}0.01 \\
(0.92)\end{array}$ & ABINE & $\begin{array}{l}-0.02 \\
(0.92) \\
\end{array}$ \\
\hline INO & $\begin{array}{c}0.38 \\
(0.04)\end{array}$ & $\mathrm{ABINO}$ & $\begin{array}{c}0.49 \\
(0.08) \\
\end{array}$ \\
\hline \multicolumn{4}{|c|}{ Lower inflation period: 1992.04-2001.12 } \\
\hline Regression 5 & & Regression 6 & \\
\hline$R^{2}$ & 0.18 & $R^{2}$ & 0.20 \\
\hline$B G$ & 0.05 & $B G$ & 0.06 \\
\hline CONSTANT & $\begin{array}{c}2.01 \\
(0.00)\end{array}$ & CONSTANT & $\begin{array}{c}1.93 \\
(0.00) \\
\end{array}$ \\
\hline TREND & $\begin{array}{l}-0.00 \\
(0.00) \\
\end{array}$ & TREND & $\begin{array}{l}-0.00 \\
(0.00) \\
\end{array}$ \\
\hline INE & $\begin{array}{l}-0.21 \\
(0.33) \\
\end{array}$ & ABINE & $\begin{array}{l}-0.25 \\
(0.26) \\
\end{array}$ \\
\hline INO & $\begin{array}{c}0.01 \\
(0.97)\end{array}$ & $\mathrm{ABINO}$ & $\begin{array}{c}0.43 \\
(0.11) \\
\end{array}$ \\
\hline
\end{tabular}


Table 6. Structural change. Argentina and Spain

\begin{tabular}{|l|c|l|}
\hline Regressions/Regimes & $\begin{array}{l}\text { Argentina } \\
\text { Lower to higher inflation } \\
(1960.01-1975.01 \text { to } \\
1975.02-1991.02)\end{array}$ & $\begin{array}{l}\text { Spain } \\
\text { Higher to lower inflation } \\
\text { (1985.09-1992.03 to } \\
\text { 1992.04-2001.12) }\end{array}$ \\
\hline RPV=f(IN) & 1 & 1 \\
\hline RPV=f(IN, DIN) & 1 & 1 \\
\hline RPV=f(IN,ABDIN) & 1 & 1 \\
\hline RPV=f(IN,VARIN) & 1 & 1 \\
\hline RPV $=f(I N E, I N O)$ & 1 & 1 \\
\hline$R P V=f(A B I N E, A B I N O)$ & 1 & 1 \\
\hline
\end{tabular}

Note:

1: Structural change was verified at the $1 \%$ level. 